\title{
Factor X Deficiency
}

National Cancer Institute

\section{Source}

National Cancer Institute. Factor X Deficiency. NCI Thesaurus. Code C131632.

A coagulation disorder characterized by the partial or complete absence of factor $X$ activity in the blood. 